\title{
$431 \mathrm{FEM}$ 汎用プログラムによる $K_{I}, K_{I I}$ の高精度解析手法の応用（2次元問題）
}

\section{Application of a commercial FEM program for calculating accurately $K_{I}, K_{I I}$ of $2 \mathrm{D}$ problems}

$\bigcirc$ 正牛島邦晴 (九産大), 西谷弘信（九大名誉），才本明秀（長崎大）, 寺西高広（九産大）

Kuniharu USHIJIMA, Kyushu Sangyo University, 2-3-1, Matsukadai, Higashi-ku, Fukuoka, 813-8503

Hironobu NISITANI, Kyushu University, 6-10-1 Hakozaki, Higashi-ku, Fukuoka, 812-8581

Akihide SAIMOTO, Nagasaki University, 1-14 Bunkyou-machi, Nagasaki, 852-8521

Takahiro TERANISI, Kyushu Sangyo University,2-3-1, Matsukadai, Higashi-ku, Fukuoka, 813-8503

Keywords; Finite Element Method, Linear Notch Mechanics, Linear Crack Mechanics, Stress Intensity Factor

\section{1 緒言}

有限要素法（FEM）はその高い汎用性により，き裂や切 欠き等の応力集中を持つ構造の応力解析に広く用いられて いる.FEM を用いて応力集中問題を精度よく解析するため には，応力場の特徵を利用した評価法が必要不可欠となる。 本研究では, 先に切欠き問題に適用した線形切欠き力学に基 づくFEM 沉用プログラムによる高精度解析手法 (1) を,き 裂を持つ構造の応力拡大係数 $\left(K_{I}, K_{I}\right)$ の算出に応用する.

\section{2 解析方法}

FEM 解析で求めたき裂あるいは切欠きによる応力分布か ら応力拡大係数または応力集中係数を精度よく求めるため には，応力場の特徵を正しく知る必要がある。ここでは一例 として，モード $I$ の様引張り応力 $\sigma_{\infty}$ を受ける無限板中に 1 個のだ円孔がある場合 (図 1 参照) を考える ${ }^{(2)}$.

切欠き底付近の $\mathrm{x}$ 軸上の応力分布は, Neuber ${ }^{(3)}$ の解を变 形することによって次のように表される。

$$
\sigma_{y}(x)=\sigma_{\infty} \cdot \frac{m^{4} \xi^{3}+m^{2}\left(m^{2}-m-3\right) \xi+m+1}{(m-1)\left(m^{2}-1\right)}
$$

ここで, $m=\sqrt{a / \rho}, \xi=(a+x) / \sqrt{a^{2}+m^{2}\left(2 a x+x^{2}\right)}$ であ る. このパラメータ $\xi を x / \rho$ の関数として表すと次式

$$
\xi=1-\frac{m^{2}-1}{m^{2}} \cdot \frac{x}{\rho}+\frac{3\left(m^{2}-1\right)}{2 m^{2}} \cdot \frac{x^{2}}{\rho^{2}}+\cdots
$$

が得られ、これを(1) 式に代入すると，応力分布は次式で表 される。

$\sigma_{y}(x)=\sigma_{\max }\left[1+\frac{3+4 m}{1+2 m} \cdot \frac{x}{\rho}+\frac{3}{2} \cdot \frac{5+6 m}{1+2 m} \cdot\left(\frac{x}{\rho}\right)^{2}+\cdots\right]$

ここで, 最大応力 $\sigma_{\max }$ は

$$
\sigma_{\max }=\sigma_{y}(0)=\sigma_{\infty}(1+2 m)
$$

である。 (3) 式において, $x / \rho,(x / \rho)^{2}$ の係数はパラメータ $m$ が $1 \sim \infty$ に变化しても大きくは変化しない $(2.33 \sim 2$ 程 度）。従ってこのことから, $x / \rho$ が小さいときの切欠き底付 近の応力分布が, 切久き負荷さ $a$ にはほとんど無関係に, 切 欠き低の最大応力 $\sigma_{\max }$ と $\rho$ のみによってほぼ決まることが わかる。このことが線形切欠き力学の背景である.

き裂 $(\rho \rightarrow 0)$ 問題の場合, パラメータ $\xi$ は

$$
\xi=\frac{(a+x)}{\sqrt{a^{2}+\frac{a}{\rho}\left(2 a x+x^{2}\right)}} \rightarrow \frac{(a+x)}{\sqrt{\frac{a}{\rho}\left(2 a x+x^{2}\right)}}
$$

となる：これを $(1)$ 式に代入し $m \rightarrow \infty(\rho \rightarrow 0)$ であること を考慮すれば，無限板中に存在する 1 個のき裂による応力 分布の正確な式が導出できる。

$$
\sigma_{y}(x) \rightarrow \sigma_{\infty} \cdot \frac{m^{4} \xi}{m^{3}}=\frac{K_{I}}{\sqrt{2 \pi x}} \cdot \frac{(1+x / a)}{\sqrt{1+x /(2 a)}}
$$

ここで,き裂先端付近 $(x / a \ll 1)$ に注目すれば次式

$$
\sigma_{y}(x)=\frac{K_{I}}{\sqrt{2 \pi x}}
$$

が導出され, 周知のようなき裂先端付近の弾性応力分布が $K_{I}$ のみによってほぼ決まることがわかる。このことが線形 き裂力学の背景である。また, モードII の場合、式 (6),(7)中 の応力 $\sigma_{y}(x)$ を $\tau_{x y}(x)$ に, 応力拡大係数 $K_{I}$ を $K_{I I}$ に書き換 えればよい.

以上のように，一様引張り応力 $\sigma_{\infty}($ または一様せん断応 力 $\left.\tau_{\infty}\right)$ を受ける無限板中に 1 個のだ円孔がある場合の切欠 き底付近の応力分布から, 切欠きおよびき裂材の弾性応力 分布の特徴が導出できる. 本研究ではこの無限板での応力 場の特徴を用い, FEMで得られた有限板での応力分布から モ一ド $I$ やモードIIIの応力拡大係数を高精度に算出するこ とを試みる。

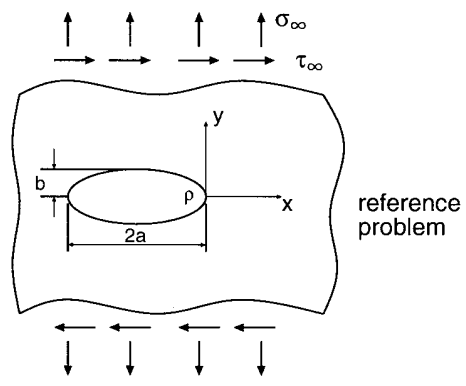

Fig.1: Ellitical Hole in an Infinite Plate

FEM を用いて実構造物の応力解析を精度よく行うために, 以下の 3 点に従い解析を進める。解析の概要を模式図 2 に 示す。

(1) 構造物全休を比較的粗いメッシュで解析し, 応力集中 部付近で応力の変化が小さい境界（=第 1 サブ境界）を 求める。

（2）第 1 サブ境界上の変位を境界条件とする，応力集中部 近傍を取り囲む領域に対し, 詳細なメッシュで解析を行 い, 応力集中部により近い領域に新たな境界 (二第 2 サ ブ境界) を設定する。

(3) 項目 (2) を第 3 , 第 4 サブ境界・と繰り返しながらシス テマティックな要素分割を行い, き裂近傍の応力分布を 算出する。 


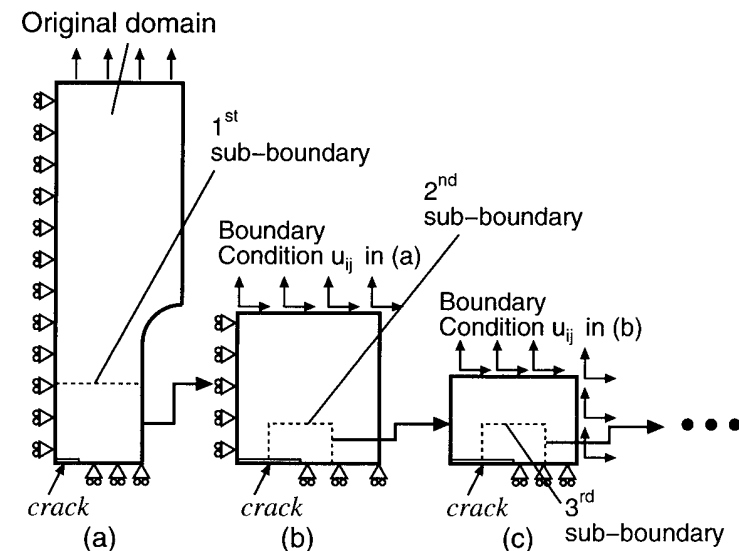

Fig.2: Overall Process of FEM Analysis

\section{3 解析結果および検討}

図 $3(a)$ はき裂長さ $a=1$ でモード $I$ の荷重を受ける時の, き裂まわりの応力 $\sigma_{y}(x)$ 分布を示す。ここで, 図中には式 $(6)$ で表される無限板中の応力場の敎密解と, 式 (7) で表される き裂先端付近 $(x / a \ll 1)$ での第一支配項を，てれぞれ実線 と破線で示している。図中の $e_{\min }$ はき裂先端付近での最小 要素の大きさを, $K_{I, \text { exact }}$ は休積力法を用いて求めた対象問 題での応力拡大係数 $K_{I}$ の秠密解である。この図からわかる ように，FEM 解析で得られた有限板内のき裂まわりの応力 場は，無限板での応力場の笪密解（式 (6)）と広範囲の $x$ で 非常に近い值を示している，すなわち，参照問題である無限 板中の応力分布と非常によく似た応力場が，解析対象の有 限板内のき裂まわりに生じている。

従って以上の結果を基に, 本研究では無限㤆内におけるき 裂問題を参照問題とし，無限板内における応力場の政密解 （式 (6)）を用いて，解析対象問題である有限板でのき裂の 応力拡大係数 $K_{I}\left(\right.$ または $\left.K_{I I}\right)$ を算出する。すなわち, FEM 解析で求めた応力分布 $\left.\sigma_{y}(x)\right|_{F E M}$ (または $\left.\left.\tau_{x y}(x)\right|_{F E M}\right)$ を 用い, 以下の式で応力拡大係数 $K_{I}$ (または $\left.K_{I I}\right)$ を算出する.

$$
\left\{\begin{array}{l}
K_{I} \\
K_{I}
\end{array}\right\}=\frac{\sqrt{2 \pi x(1+x /(2 a))}}{(1+x / a)} \cdot\left\{\begin{array}{l}
\left.\sigma_{y}(x)\right|_{F E M} \\
\left.\tau_{x y}(x)\right|_{F E M}
\end{array}\right\}
$$

図 $3(b)$ は式 $(8)$ を用いて求めた応力拡大係数 $K_{I}$ の相対誤差を 表す。この図からわかるように，き裂尙端近傍 $\left(x<20 e_{m i n}\right)$ から離れた場所の応力分布 $\left.\sigma_{y}(x)\right|_{F E M}$ から求めた応力払大 係数 $K_{I}$ は，体積力法での铰密解との相対誤差が $0.5 \%$ 以内 に収まる高精度な解を得ている。

図 4 は分割サイズ $e_{\text {min }}=1 / 243$ での応力結果から求めた, 応力拡大係数 $K_{I}$ の相対誤差を示している. 図中には比較の ため, 通常用いられるき裂先端近傍で第一支配項となる式 （7）を基にして, 次式

$$
K_{I}=\left.\sqrt{2 \pi x} \sigma_{y}(x)\right|_{F E M}
$$

で求めた応力拡大係数 $K_{I}$ の相対誤差も○印で示している. き裂先端から離れるに従い, 式 (9)により求めた $K_{I}$ の相対 䛊差は急激に増加する。一方，無限板中の応力場の備密解を

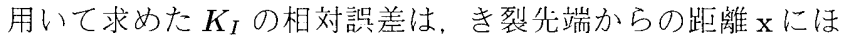
ぼ無関係に一定で高精度 $(0.2 \%$ 以内の䛊差 $)$ である。また, 式 (8)による誤差の大きさは同じ分割サイズ $e_{\min }$ であれば き裂長さに依仔しないことがわかる. (結言, 参考文献省略).

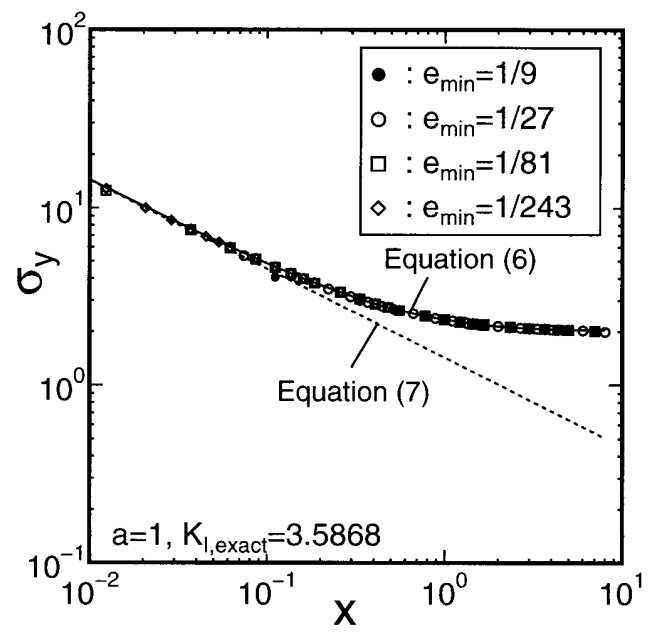

(a) Distribution of Stress $\sigma_{y}$

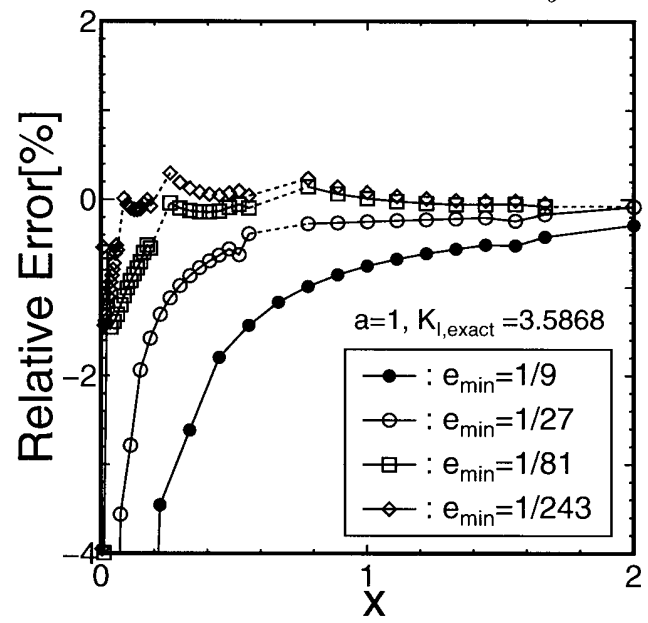

(b) Relative Errors of Stress Intensity Factor $K_{I}$

Fig.3: Comparisons of $\sigma_{y}$ and Relative Error of $K_{I}$ under Different Mesh Size $e_{\min }$

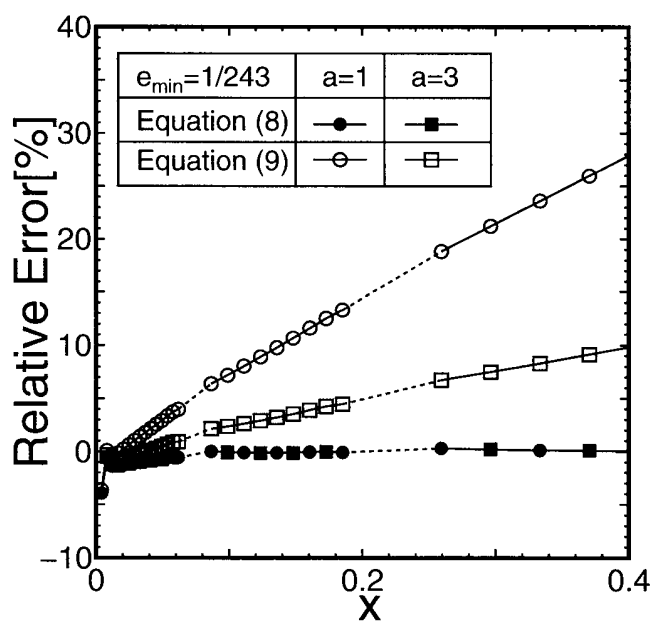

Fig.4: Comparisons of Relative Error of $K_{I} \mathrm{Ob}-$ tained by Different Estimate Equation (8) and (9) 